\title{
CrimRxiv
}

\section{Does Education Affect}

Environmental Crime? A

\section{Dynamic Panel Data}

\section{Approach at Provincial} Level in Italy

Angelo Castaldo $^{\mathbf{1}}$, Anna Rita Germani ${ }^{1}$, Antonio Pergolizzi ${ }^{2}$

1"Sapienza" University of Rome, ${ }^{2}$ Legambiente Onlus

Published on: May 19, 2021

License: Creative Commons Attribution 4.0 International License (CC-BY 4.0). 


\begin{abstract}
:
This paper investigates the role of education on environmental crime in Italy, using a panel of 110 Italian provinces over the period 2010 to 2015. We employ a system-GMM dynamic panel data approach to tackle the endogeneity that might arise in the estimations from the environmental crime dynamic path and to consider time-invariant effects on provinces. Our empirical results, even after controlling for socio-economic and judicial efficiency characteristics, support the existence of a $U$-inverted relationship between education and environmental crime, that depicts an unconventional finding: at the margin, a higher level of education endowment offsets the propensity to commit environmental crimes, which are confirmed to be white-collar type of crimes. The results are robust to model specifications and endogeneity. Furthermore, to check the robustness of non-monotonicity in the relationship between environmental crime and education, and to control for unobserved provincial heterogeneity, we also exploit a semi-parametric fixed effects model. There is wide room for efficiency gains that could arise from policy interventions aiming to put environmental crimes into perspective.
\end{abstract}

Keywords: environmental crime, education, system-GMM, semi-parametric fixed effects model, Italy.

\title{
JEL classifications: Q56, K32.
}

\section{INTRODUCTION}

The problems and the consequences caused by environmental crimes in contemporary societies and suggested approaches of intervention are gaining increasing relevance worldwide. However, despite the growing awareness of the phenomenon at community, political and institutional levels, very little is known, from an empirical point of view, about the determinants and the nature of environmental crimes. In Italy, every year environmental criminals produce billion-dollar business to the detriment of the wellbeing of the territory and of its people. Only in 2018, 1.2 million tons of special hazardous waste were illegally trafficked, over 17,000 violations in the construction sector have been perpetrated, and its cultural heritage and the protected flora and fauna have been plundered (Legambiente, 2019). These numbers are emblematic in that they bear witness to the strength and the growth of the volume of illegal environmental markets that range from the illegal traffic of waste to the illegal trade of 
wildlife and cultural heritage, from counterfeiting in the agri-food sector to forest fires and illegal construction.

In Italy, in addition to widespread and high levels of corruption, other problems are often associated with environmental crime, such as i) non-uniform application of administrative controls and enforcement actions, especially at local level (i.e., monitoring, inspections, authorizations, etc.); ii) lack of coordination among the several authorities involved in the enforcement of environmental laws and regulations that often work independently; iii) legal uncertainty due to perennial changes in legislation that do not make clear the distinction between legal and illegal actions (i.e., end of waste policy) together with incoherent and sometimes "criminogenic" features of the laws (meaning by this that norms or regulations might contain elements that can be a potential source of inspiration and justification in committing illegal actions); iv) regional variations in the amount of plant equipment (i.e., for waste recycling and recovery treatments); v) presence of eco-criminal structures (i.e., mafia-like organizations) that offer wide-spread safe-havens to eco-criminals; vi) weak social awareness of environmental crime and its victims. In addition to these aspects, in Italy, there has been not only a lack of economic resources devoted to environmental crime prevention and control, but also a problem of collusion between political parties and industrial lobbies that has affected, for several years, the criminal environmental legislation and its effective enforcement. All these circumstances have created the prevalence of a system that, over time, has allowed easy private profits generating huge environmental and social costs (D’Alisa et al., 2017).

Furthermore, the massive production of laws and regulatory modifications have created a normative chaos: the main normative instruments in the protection of the environment, in fact, are still scattered in several different laws, such as Legislative Decree 152/2006 (which regulates the waste management process, soil and the fight against desertification, water pollution and the management of water resources, and air emissions); Legislative Decree 380/2001 (which regulates the building sector); Legislative Decree 42/2004 (the so-called Cultural Heritage Code), and the Penal Code. Only recently, the Law 68/2015 has introduced a new Chapter (VI bis) to the Italian Penal Code devoting it to crimes against the environment and defining some new types of crimes: intentional crimes, environmental pollution and fatal injuries, traffic and abandonment of high radioactivity material, environmental disaster. Due to this recent law reform directed at the strengthening of environmental criminal enforcement, we believe that our findings should assist policymakers in identifying the drivers of environmental crimes. 
Environmental crime often goes hand in hand with white collar types of crimes throughout the criminal chain (Nelleman et al., 2016). Unlike with other forms of more naïve criminal activities, eco-criminals have to know the legal market and its operational dynamics, the complex structure of regulatory frameworks, and the strengths and weaknesses of the monitoring and enforcement system. In addition, environmental crime is usually attached to multiple and complex criminal behaviors that require connections with other types of conduct, such as, corruption, fraud and money laundering activities (Pergolizzi, 2019). This complexity supports the basic idea that these are forms of crime that need highly skilled and sophisticated professional abilities. In contrast with the public's simplistic opinions and prevailing views that organized crime is responsible for most environmental crime in Italy, more recently, Italian authorities (i.e., National Anti-Mafia Directorate) have emphasized that corporations with no mafia connections very often commit environmental crimes (Roberti, 2014; de Falco, 2014), advocating a widening in their classification towards a broader corporate crime definition rather than exclusively mafia-type of crimes. Despite the increasing attention at the social, political and institutional levels, environmental illegality is still an under-investigated issue in the empirical literature. This study attempts to fill this gap by exploring whether income and socio-economic characteristics may have a role in explaining environmental crime. Specifically, we aim to examine the relation between education and environmental crime to assess if education might play a prominent role in explaining the evolution of the phenomenon.

Starting from the seminal work by Becker (1968) on the economic approach to studying criminal behavior, and following Ehrlich (1973) who provided one of the first analyses on the impact of education on crime, economists have been interested to estimate the strength of this relationship which is, a priori, ambiguous, given that the net effect of educational attainment on criminal behavior may reduce the cost of committing a crime, but may also raise the resulting revenues (Lochner, 2011). Theory suggests that education may affect the criminal decision in several ways. First, higher/lower levels of education, being associated with higher/lower wages, may increase/decrease the opportunity cost to commit a crime (Lochner, 2004)를 income effect, working through education increases the returns from legitimate works or raises the opportunity cost of illegal behavior (Grogger, 1998; Machin and Meghir, 2004); second, forward-looking individuals may learn to be more patient through schooling, placing more weight on their potential future (legal) earnings, and may become more risk adverse (Lochner and Moretti, 2004; Becker and Mulligan, 1997); in addition, time spent in education may limit the time available for participating in 
criminal activity (Tauchen et al., 1994; Hjalmarsson, 2008), and affect the individual's perception of crime generating a sort of "civilization" effect (Fajnzylber et al., 2002). Moreover, it is possible that criminal behavior is characterized by hysteresis or inertia so that the probability of committing crime today depends on the amount of crime committed in the past (Lochner and Moretti, 2004; Fajnzylber et al., 2002).

Despite the evidence that education levels attainments (i.e., quantitative measures) exerts a relevant effect on the propensity to commit crime, the recent empirical literature has started to investigate the interaction between quantitative and qualitative specifications of schooling. There is, indeed, a growing evidence that improvements in school quality may lead to reductions in criminal activity during early adulthood (Lochner, 2020; 2011b). Cullen, Jacob, and Levitt (2006) and Deming (2011) find that students who "win" the opportunity to attend better-performing public schools commit significantly less crime. However, the latest analysis of Cano-Urbina and Lochner (2019) offers mixed evidence regarding the effects of school quality (measured by pupil-teacher ratios, term length, and teacher wage rates) on female crime. In particular, while the estimated direct effects of school quality improvements are inconsistent across measures of both quality and crime, the indirect effects of school quality improvements are positive for all quality measures but are generally modest in size.

Consistently with a human capital-based theory of crime, as the empirical evidence shows, education can display an important role in reducing the inclination to commit crimes (Lance and Enrico, 2004; Lochner, 2004; Lochner and Moretti, 2004; Buonanno and Leonida, 2006, 2009; Lochner, 2007; Machin et al. 2011; Hjalmarsson et al., 2015) but indeed the effect could be uncertain (Groot et. al., 2010) when considering the probability of committing white collar crimes (i.e., tax fraud). $\underline{2}$ These ambiguous findings are linked to the different types of crime considered, to the age and the gender of the offenders, and to the motivating factors behind them (Veselak, 2015). For instance, Ochsen (2010) finds no impact of education on theft, but a negative effect on assault, while Buonanno and Montolio (2008) find a negative impact of education on property crimes, but not on violent crimes. In the light of these heterogeneous results, Bell et al. (2016) emphasize the need for a deeper understanding of the mechanisms that drive these differences.

There is, thus, widespread evidence that education is one of the main determinants of crime in general. To the best of our knowledge, there is only one published study focusing on the role of education and its impact on common crime in Italy. Specifically, 
Buonanno and Leonida (2006) by employing a GMM panel data instrumental variable approach and using regional data related to the period 1980-1995, found that average years of schooling have a negative and significant effect on crime rate. With respect to this contribution, our study expands the investigation to environmental crime, which, as far as we know, has only very recently started to be empirically explored in Italy (Germani et al., 2020). The scant attention given to Italy in the economic literature on environmental crime is rather surprising given the presence of eco-mafias (D'Amato et al., 2013) and the emergence of resource-related crimes in the last decades. The analysis is conducted at provincial level to investigate the existence of differences in the determinants of environmental crimes. Italy is a compelling case-study also due to the country's high heterogeneity in terms of socio-economic, environmental, and institutional characteristics (Costantini et al., 2013; Mazzanti et al., 2008, 2012).

Our findings offer novel insights into the under-explored relationship between educational and environmental crime, showing a very interesting result, inasmuch as the functional relationship between education and environmental crime is U-inverted, controlling for institutional and socio-economic characteristics, in the Italian provinces over the period 2010 to 2015. The positive relationship between levels of education and environmental crime can be explained by the nature of the crime itself: being a typical economic crime, it seems to be a prerogative of subjects with higher levels of education (sophisticated agents), since the underlying illegal mechanisms require high skills to elude control (and counterfeit official documents $\underline{3}$ ) and specific investments. The negative relationship between education (in its quadratic term) and environmental crime indicates that more educated people have a higher moral stance and a stronger environmental awareness, enhancing social control mechanisms able to limit green criminal behaviors. The paper is organized as follows. Section II describes the data, the variables, and the empirical framework. Section III presents the empirical results. Section IV concludes.

\section{DATA AND EMPIRICAL FRAMEWORK}

\section{Data description}

Our panel is composed of annual data for the 110 Italian provinces (NUTS-3) over a sixyear period time (2010 to 2015). Data were collected from three different sources: the Italian Statistical Agency (ISTAT), the Istituto Tagliacarne/Union of Italian Chambers of Commerce, and Legambiente. Our outcome variable, Environmental Crime, is structured on the base of four macro-groups of crimes: i) illicit disposal of waste; ii) illegal construction/building; iii) against archaeological heritage; and iv) against 
wildlife and forest heritage. $\underline{4}$ Environmental crimes are measured in terms of the total number of violations detected by year and province. $\underline{5}$

When looking at the geographical distribution of our target variable, it is possible to highlight a strong territorial heterogeneity, coherent with a broad North-South unbalance. Figure 1 shows the provincial average number of environmental crimes committed (278) in the period 2010-2015. The heterogeneity persists in each year during the time span considered. In the four regions with traditionally higher mafia presence (Calabria, Campania, Puglia and Sicily), an average of 14,493 violations were recorded in the specified timespan. At the top of the ranking, we find the Southern provinces of Naples (1747), Salerno (1430) and Bari (1238). However, some Northern/Central provinces also, such as Genova in Liguria and Latina in Lazio, stand above the average. It is worth pointing out that, in particular, the Campanian provinces of Naples, Salerno, and Caserta (in the so-called "Land of Fires" area) are a strong focal point of environmental crimes due to the well-known practices of illegal disposal of waste and illegal construction (Legambiente, 2018).

Our strategic determinant is education, defined as the average years of study of the population aged at least 25 years. In further pinning down the role of education on environmental crime we control for socio-economic and institutional factors (population, unemployment, household's income, judicial inefficiency, total reported crimes). The correlation between unemployment and crime has been widely investigated in the literature, although the strength of this relationship remains ambiguous both in its nature and in its robustness (see Chalfin and McCrary 2017 for a comprehensive review of this literature). In line with previous studies (Buonanno et al., 2017; Buonanno and Montolio, 2008), per capita GDP that, in our study, is presented in the specification of household income, can be considered as a proxy for the general level of wealth in the provinces. The length of the proceedings, defined in terms of average length (expressed in number of days) of all criminal trial proceedings, is considered as a measure of the inefficiency of the judicial system at provincial level. $\underline{67}$ Arguably, environmental crime will be higher in provinces with less efficient courts, since long trials are likely to postpone the timing of punishment (Becker, 1968), and this could be a relevant factor inducing individuals and firms to undertake illegal activities. Drawing on empirical results from the economic geography literature, we also include geographical fixed effects (i.e., area, density); several studies have, indeed, found differences in the spatial distribution of crime (Freeman et al., 1996; 
Hudson, 2014). Crime is also typically heterogenous across territorial areas (Myers, 1982; Glaeser and Sacerdote, 1999).

Figure 1: Territorial (province-level) distribution of environmental crime (average values, 2010-2015) 


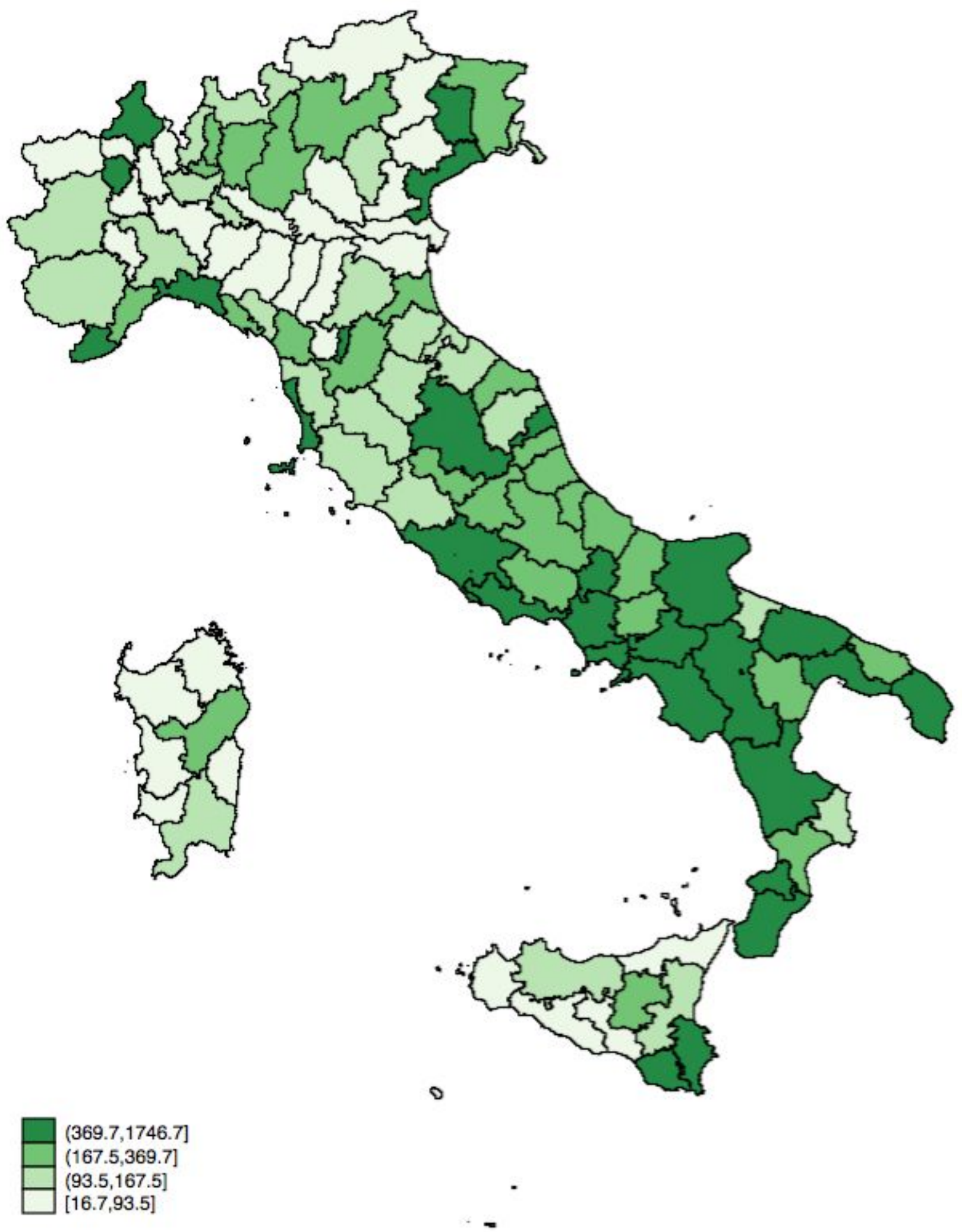

Source: author's elaboration on Legambiente data 
Tables 1 and 2 provide an overview of the selected variables and their summary statistics. A cursory look illustrates significant heterogeneity in our variables, especially for a province panel covering a relatively short time period.

Table 1 - Variable Description and Data Sources

\begin{tabular}{|c|c|c|}
\hline Variable & Description & Source \\
\hline Environmental Crime & $\begin{array}{l}\text { number of environmental } \\
\text { violations in the Italian } \\
\text { provinces }\end{array}$ & Legambiente - years 2010-2015 \\
\hline Education & $\begin{array}{l}\text { average years of study of the } \\
\text { population aged at least } 25 \\
\text { years }\end{array}$ & ISTAT \\
\hline Area & $\begin{array}{l}\text { size of the territory of the } \\
\text { province }\left(\mathrm{in} \mathrm{km}^{2} \text { ) }\right.\end{array}$ & ISTAT \\
\hline Density & ratio: inhabitants over $\mathrm{km}^{2}$ & ISTAT \\
\hline Unemployment & rate of unemployment & ISTAT \\
\hline Household Income & $\begin{array}{l}\text { taxable income per declarant } \\
\text { expressed in } €\end{array}$ & Tagliacarne Institute \\
\hline Judicial Inefficiency & $\begin{array}{l}\text { criminal trials length } \\
\text { (expressed in number of days) } \\
\text { divided by the population }\end{array}$ & Italian Ministry of Justice \\
\hline Population & number of inhabitants & ISTAT \\
\hline Total Crimes & number of total reported crimes & ISTAT \\
\hline
\end{tabular}

Table 2 - Descriptive Statistics

\begin{tabular}{|l|l|l|l|l|l|}
\hline Variables & Obs & Mean & Std. Dev. & Min & Max \\
\hline $\begin{array}{l}\text { Environmental } \\
\text { Crime }\end{array}$ & 660 & 278.973 & 320.184 & 1 & 2569 \\
\hline
\end{tabular}




\begin{tabular}{|l|l|l|l|l|l|}
\hline Education & 660 & 9.812 & .562 & 8.305 & 11.716 \\
\hline Area & 660 & $2,739.436$ & $1,573.64$ & 212 & 7,400 \\
\hline Density & 660 & 260.718 & 370.36 & 30.9 & 2652.7 \\
\hline $\begin{array}{l}\text { Unemploymen } \\
\text { t }\end{array}$ & 660 & 11.192 & 5.428 & 2.69 & 31.46 \\
\hline $\begin{array}{l}\text { Household } \\
\text { Income }\end{array}$ & 660 & $22,381.49$ & $2,176.221$ & $17,936.9$ & $31,581.65$ \\
\hline $\begin{array}{l}\text { Judicial } \\
\text { Inefficiency }\end{array}$ & 660 & .001 & .001 & 0 & .006 \\
\hline Population & 660 & $546,496.9$ & $596,361.2$ & 57,318 & $4,342,046$ \\
\hline Total Crimes & 660 & $25,121.31$ & $38,859.54$ & 1241.569 & 278,255 \\
\hline
\end{tabular}

Identification strategy

Since the theoretical framework created by Becker (1968) and developed by Ehrlich (1973), in which individuals are rational decision makers who decide to engage in legitimate or illegitimate activities according to their respective expected returns, a variety of models have been developed in attempts to verify whether education may have positive or negative effects on criminal behavior (Lochner, 2020). The decision to engage in illegitimate activities depends on variables i) characterizing the alternatives to illegitimate activities, and ii) affecting returns to illegitimate activities including the probability of being caught, punished and the severity of sanctions. A large body of this literature (Lochner and Moretti, 2004; Buonanno and Leonida, 2009) has pointed out that education, unemployment and per-capita income are introduced to capture the effect of legitimate opportunities and are important factors in explaining individuals' criminal attitude. A further relevant theoretical framework is the one advanced by Lochner (2004) who explores the relationship between education and crime within the traditional Becker (1967) and Ben-Porath (1967) human capital investment models. This approach recognizes that education increases human capital levels and market wage rates, which raise the costs of engaging in crime; while unskilled crimes should be negatively correlated with education, for white collar crimes it is suggested that education should increase the returns to crime. Given that the education-crime relationships might depend on the skill content of crime (Lochner, 2011a; Germani et 
al., 2020), these predictions are empirically examined in our work with the aim i) to investigate the interaction between environmental crime and education, and ii) to verify the existence of a possible inverse $U$-shaped relationship.

In this context, a first approach requires a correlation analysis that primarily tests the existence of a link between the annual number of environmental criminal violations and education in each province, controlling for judicial efficiency, socio-economic variables, and time. Panel data (years 2010-2015) at provincial level is used for the empirical estimation. The OLS estimation equation takes the following form:

$$
\mathrm{EC}_{\mathrm{it}}=\beta_{0}+\beta_{1} \mathrm{EDUit}+\beta_{2} \mathrm{EDU}^{2} \mathrm{it}+\beta_{2} X \mathrm{it}+T_{t}+\mathrm{FE}_{i}+\varepsilon_{\mathrm{it}}(1)
$$

where, the subscripts $i$ and $t$ represent respectively the province and the time period, $E C$ is the number of environmental crimes, $E D U$ is the average years of study of the population aged at least 25 years, and $X$ is a vector of socio-economic and institutional variables, $T$ and $F E$ are, respectively, years and geographical fixed effects, $\varepsilon$ is the timevarying error term which stands for a well-behaved error term distributed IID $\left(0, \sigma^{2}\right)$. All variables are expressed in natural logarithms. This first approach provides the OLS panel estimate fixed (FE) and random (RE) effects models. To choose the most efficient estimation strategy, we performed both the Breusch-Pagan Lagrange Multiplier Test (1980) and the Hausman Test (1978), which reveal that the fixed effects estimation model is the most appropriate one.

The empirical crime literature takes into account the possibility of criminal hysteresis or inertia (Fajnzylber et al., 2002) for which todays' crime rates are related to previous crimes rates. Past crime may affect current criminal behavior for several reasons. Criminals can acquire criminal know-how throughout a learning by doing process, which might allow them to reduce their expected cost of carrying out criminal acts. Furthermore, the fewer legal job opportunities (Grogger, 1995) that convicted criminals are likely to have, may reduce their cost of participating in criminal activity and make the commission of crime more attractive. For these reasons, the relevance of a dynamic path associated to environmental crimes suggests that OLS coefficients could be inconsistent due to the correlation of $E C_{t-1}$ and the error term, even when relying on a first difference set up. Therefore, we employ a dynamic panel data analysis (Holtz-Eakin, Newey and Rosen, 1988; Arellano and Bond, 1991; Arellano and Bover, 1995; Blundell and Bond, 1998), which allows us to enhance the accuracy of the OLS estimates through an auto-regressive approach. In the choice of the technique to implement, Blundell and Bond (1998) point out that the first-differenced GMM 
estimators are likely to be inefficient, holding poor finite sample properties when the series are highly persistent (i.e., lagged levels of the series provide weak instruments for the differenced equations). When the panel units are large and the time periods are small, the system-GMM estimator (Arellano and Bover, 1995) is more efficient (Baltagi, 2005) then the difference-GMM estimator (Arellano and Bond, 1991). This argument provides a first suggestion that in our case (with $\mathrm{N}=110$ and $\mathrm{T}=6$ ) the application of the system-GMM is to be preferred. Moreover, following Blundell and Bond (1998) and Bond (2001), our choice is also confirmed by comparing the coefficients magnitude of the lagged dependent variable from the difference- and the system-GMM, with those obtained by the pooled OLS and the panel fixed effects (P-FE), which likely provide the upward- and downward-bound bias of the estimates. As a result, the difference-GMM estimate leads to a coefficient of the lagged dependent variable below the fixed effects estimate. In our panel, this finding reveals a downward bias of the difference-GMM estimator that is coherent with the finite sample bias (Blundell and Bond, 1998). Conversely, the system-GMM estimator obtains a coefficient that is lower than the OLS and higher than the fixed effects coefficients; this entails that the system-GMM estimator has to be preferred.

Therefore, to deal with the dynamic and simultaneity problems, we estimate through a system-GMM (Arellano and Bond, 1991; Arellano and Bover, 1995), a more efficient model of crime, which posits a relationship between annual reported environmental crimes in each province and education, controlling for the previous set of socioeconomic and institutional variables. The system-GMM estimation takes the following equation form:

$\mathrm{EC}_{\mathrm{it}}=\beta_{0}+\beta_{1} \mathrm{EC}_{i t-1}+\beta_{2} \mathrm{Edu}_{\mathrm{it}}+\beta_{3} \mathrm{Edu}_{\mathrm{it}}^{2}+\beta_{4} X_{\mathrm{it}}+\eta_{i}+\xi_{t}+\varepsilon_{\mathrm{it}}$

where, the subscripts $i$ and $t$ represent the province and the time period, respectively. All variables are expressed in natural logarithms. The dependent variable is the environmental crime, while the explanatory variables are the lagged environmental crime rate, the level of education and a vector $(X)$ of socio-economic and institutional variables characterizing the type of crime considered. The lagged dependent variable (environmental crime ${ }_{i, t-1}$ ) was inserted into the model in order to identify the persistency in the dynamics of crime; $\eta_{i}$ is a province fixed effect and $\xi_{t}$ a time fixed effect; $\varepsilon_{\text {it }}$ stands for a well-behaved error term distributed IID $\left(0, \sigma^{2}\right)$.

The system-GMM estimator (Arellano and Bond, 1991; Arellano and Bover, 1995) $\underline{8}$ allows to control for time-invariant province specific effects and for tackling the 
endogeneity criticalities that arise from the lagged value of environmental crime. Moreover, whether heteroskedasticity is present or not, the GMM estimator is more efficient than alternative IV estimators; finally, it admits an unavoidable degree of endogeneity for the socio-economic and institutional regressors and maximizes the value of the data by combining information on cross province variation in levels and differences.

The Arellano and Bond (1991) estimator exploits the lagged values of the endogenous variables as instruments: the use of these internal instruments enhances the accuracy of the estimates, as showed by several empirical crime studies (Bun et al., 2020; Bun, 2014; Witt et al., 1999). In particular, the selection of the instruments may be tricky. In order to avoid the risk of bias associated to large sets of lags, as in Leonida et al. 2013, we implement a parsimonious instrument selection approach that relies on lags $t=-2$ and $t=-3$ for all the regressors, and assume that these instrumental variables are uncorrelated with the error term. This choice minimizes the risk of the estimation bias since we ground our instrumental approach, on the consistency of the basic model specification, without recurring to further external instruments.

We test the validity of the instruments by applying two specification tests: a) the Sargan (1958) test of over-identifying restrictions to examine the consistency of the instruments. Failure to reject this null hypothesis gives support to the model; b) the Arellano and Bond (1991) test for the serial correlation of the disturbances up to the second order. Failure to reject the null hypothesis of no second-order serial correlation implies that the original error term is serially uncorrelated, and the moment conditions are correctly specified.

The consistency of the estimator, however, strictly depends on the validity of the instruments. An instrumental variable, in particular, besides being correlated with the endogenous variable included must be orthogonal to the error process. An issue arising when investigating environmental crime heterogeneity across provinces, lies in the fact that the level of total criminality could represent a missing confounding variable. In order to tackle such a drawback and provide a robustness check to our estimates, we add total crimes to the set of regressors and we also specify our outcome variable as the ratio of environmental crimes to total crimes. $\underline{9}$

Finally, in order to ascertain the robustness of our education quadratic specification, we also implement the alternative two-stage semiparametric fixed effects additive model (Baltagi and Li, 2002): 
$\mathrm{EC}_{\mathrm{it}}=\propto_{i}+\beta_{1} X_{\mathrm{it}}+\beta_{2} \mathrm{FE}_{\mathrm{it}}+g\left(\mathrm{Edu}_{\mathrm{it}}\right)+\nu_{\mathrm{it}}$ (3)

$E C /$ Trimes $_{\mathrm{it}}=\propto_{i}+\beta_{1} X_{\mathrm{it}}+\beta_{2} \mathrm{FE}_{\mathrm{it}}+g\left(\mathrm{Edu}_{\mathrm{it}}\right)+\nu_{\mathrm{it}}$

where EC and EC/Tcrimes represent, respectively, environmental crimes and the ratio of environmental crimes to total crimes, Edu enters the model nonlinearly, $X$ is a vector containing province-specific time-varying socio-economic and judicial controls, FE are the regional and year fixed effects to control for unobserved heterogeneity, and $\nu_{i t}$ is the error term. All variables are expressed in natural logarithms. The additive model satisfies the stochastic equicontinuity condition and is pointwise asymptotically normal. Thus, it achieves the standard one-dimensional rate of convergence, and has the same asymptotic accuracy as if the nuisance terms were known with certainty. Moreover, for the parametric component, the estimates of the parameters are asymptotically normal. Note, we estimate $g(\bullet)$ using kernel-weighted local polynomial smoothing. In the parametric part of the estimation, we include the previous set of controls $X$ and the years.

\section{ESTIMATION RESULTS AND DISCUSSION}

The preliminary estimations of (1) both using panel fixed (FE) and random (RE) effects models are presented in Table 3. Models (a) and (b) show the results of the baseline model where environmental crime is regressed only against our strategic explanatory variable, i.e., education and education ${ }^{2}$. In models ( $c$ ) and (d), socio-economic and deterrence controls are added. Even though the signs, magnitude and statistical significance of the coefficients are very similar across the two different estimation methods, according to the Breusch-Pagan Lagrange Multiplier (1980) and the Hausman tests (1978), the FE estimation, due to the higher efficiency, is preferred to the RE model. Therefore, the FE model in column $(c)$ is our preferred specification.

The overall estimates reveal that, in this preliminary stage of analysis, the effect exerted by education on environmental crime is consistent, and it appears to be nonlinear. The combination of the positive and highly statistically significance of education (+118.1, at $1 \%$ significance level) and the negative and highly statistically significance of its quadratic term (-25.5, at 1\% significance level) supports the existence of a U-inverted shape relationship between education and environmental crime. However, OLS estimates could be inconsistent given the endogeneity deriving from the omission of the dynamic pattern of environmental crimes (i.e., the correlation between $E C_{t-1}$ and the error term). Given these limitations, we rely on the alternative system-GMM dynamic panel analysis. 
Table 3 - Panel OLS: estimation results

\begin{tabular}{|c|c|c|c|c|}
\hline Variables & (a) & (b) & (c) & (d) \\
\hline $\begin{array}{l}\text { Dep. Var.: } \\
\text { Environmental } \\
\text { crime }\end{array}$ & Panel-FE & Panel-RE & Panel-FE & Panel-RE \\
\hline Education & $\begin{array}{l}115.745^{* *} \\
(46.95)\end{array}$ & $\begin{array}{l}99.174^{* *} \\
(49.50)\end{array}$ & $\begin{array}{l}150.125^{* * *} \\
(43.80)\end{array}$ & $\begin{array}{l}100.269 * * \\
(39.09)\end{array}$ \\
\hline Education $^{2}$ & $\begin{array}{l}-26.391 * * \\
(10.32)\end{array}$ & $\begin{array}{l}-22.623^{* *} \\
(10.89)\end{array}$ & $\begin{array}{l}-32.596^{* * *} \\
(9.642)\end{array}$ & $\begin{array}{l}-22.130^{* *} \\
(8.572)\end{array}$ \\
\hline $\begin{array}{l}\text { Judicial } \\
\text { inefficiency }\end{array}$ & & & $\begin{array}{l}106.479 \\
(71.76)\end{array}$ & $\begin{array}{l}66.50374 \\
(77.40)\end{array}$ \\
\hline Unemployment & & & $\begin{array}{l}0.0138 \\
(0.011)\end{array}$ & $\begin{array}{l}0.016 \\
(0.012)\end{array}$ \\
\hline $\begin{array}{l}\text { Households } \\
\text { income }\end{array}$ & & & $\begin{array}{l}335.079 \\
(369.3)\end{array}$ & $\begin{array}{l}1508.549 \text { *** } \\
(366.6)\end{array}$ \\
\hline $\begin{array}{l}\text { Households } \\
\text { income }^{2}\end{array}$ & & & $\begin{array}{l}-17.156 \\
(18.53)\end{array}$ & $\begin{array}{l}-76.257^{* * *} \\
(18.39)\end{array}$ \\
\hline Population & $\begin{array}{l}1.241 \\
(2.729)\end{array}$ & $\begin{array}{l}0.689 * * * \\
(0.134)\end{array}$ & $\begin{array}{l}5.809 * * \\
(2.850)\end{array}$ & $\begin{array}{l}0.691^{* * *} \\
(0.101)\end{array}$ \\
\hline Years & Yes & Yes & Yes & Yes \\
\hline Geographical FE & - & Yes & - & Yes \\
\hline Cons. & $\begin{array}{l}-145.269 * * \\
(64.72)\end{array}$ & $\begin{array}{l}-118.180^{* *} \\
(56.33)\end{array}$ & $\begin{array}{l}-242.725^{* * * *} \\
(0.001)\end{array}$ & $\begin{array}{l}-117.282^{* * *} \\
(0.008)\end{array}$ \\
\hline F-Stat. /Wald Test & $13.15 * * *$ & $117.50^{* * *}$ & $10.16^{* * *}$ & $148.44^{* * *}$ \\
\hline
\end{tabular}




\begin{tabular}{|l|l|l|l|l|}
\hline $\begin{array}{l}\text { N. of obs. } \\
\text { N. of Groups } \\
\text { (provinces) }\end{array}$ & 657 & 657 & 548 & 548 \\
\hline $\begin{array}{l}\text { Robust standard } \\
\text { errors in } \\
\text { parentheses, * } \\
\text { p<0.1, ** p<0.05, } \\
* * * p<0.01\end{array}$ & & & 110 & 110 \\
\hline
\end{tabular}

The GMM-system estimation results and tests are reported in Table 4. The statistical tests that have been carried out are: i) the joint significance of time dummies (Wald test), ii) the Arellano-Bond (1991) for the first and second order serial correlation, iii) the Sargan (1958) and iv) the Hansen (1982) of over-identifying restrictions. Moreover, in all the estimated models, with the exception of area, regressors are treated as endogenous. In all model specifications time dummies are jointly significant. In synthesis, in a general perspective, all the estimations obtained reveal that green crimes are influenced by the socio-economic, territorial, and judicial characteristics of the provinces.

\section{Table 4 - System-GMM: estimation results}

\begin{tabular}{|c|c|c|c|}
\hline Variables & (a) & (b) & $(c)$ \\
\hline $\begin{array}{l}\text { Dep. Variable: } \\
\text { Environmental crime }\end{array}$ & System-GMM & System-GMM & System-GMM \\
\hline Environmental crime $_{t-1}$ & $\begin{array}{l}0.928 * * * \\
(0.0588)\end{array}$ & $\begin{array}{l}0.983 * * * \\
(0.0506)\end{array}$ & $\begin{array}{l}1.239 * * * \\
(0.178)\end{array}$ \\
\hline Education & $\begin{array}{l}445.683^{* *} \\
(224.8)\end{array}$ & $\begin{array}{l}389.873^{* *} \\
(178.4)\end{array}$ & $\begin{array}{l}273.842^{* * *} \\
(97.97)\end{array}$ \\
\hline Education $^{2}$ & $\begin{array}{l}-92.904 * \\
(48.63)\end{array}$ & $\begin{array}{l}-81.057^{* *} \\
(38.79)\end{array}$ & $\begin{array}{l}-58.658^{* * *} \\
(20.90)\end{array}$ \\
\hline
\end{tabular}




\begin{tabular}{|c|c|c|c|}
\hline Judicial inefficiency & & $\begin{array}{l}865.022 \\
(1103.1)\end{array}$ & $\begin{array}{l}941.884^{* * *} \\
(340.41)\end{array}$ \\
\hline Unemployment & & & $\begin{array}{l}1.685 \\
(1.648)\end{array}$ \\
\hline Households' income & & & $\begin{array}{l}700.629 * * \\
(319.2)\end{array}$ \\
\hline Households income $^{2}$ & & & $\begin{array}{l}-34.514^{* *} \\
(15.86)\end{array}$ \\
\hline Population & $\begin{array}{l}-4.893 \\
(5.487)\end{array}$ & $\begin{array}{l}-5.267 \\
(7.411)\end{array}$ & $\begin{array}{l}-5.624 \\
(24.61)\end{array}$ \\
\hline Area & & $\begin{array}{l}1.09881 \mathrm{e}-05 \\
(0.000)\end{array}$ & $\begin{array}{l}9.75573 e-05 \\
(0.000)\end{array}$ \\
\hline Cons. & $\begin{array}{l}0.111 \\
(0.302)\end{array}$ & $\begin{array}{l}-0.2057 \\
(0.282)\end{array}$ & $\begin{array}{l}-355.725^{* *} \\
(160.67)\end{array}$ \\
\hline Wald Test (Time) & $652.25^{* * *}$ & $479.32 * * *$ & $128.28^{* * *}$ \\
\hline $\begin{array}{l}\text { Arellano-Bond Test for } \\
\operatorname{AR}(1)-\operatorname{Pr}>\mathrm{z}\end{array}$ & 0.000 & 0.000 & 0.009 \\
\hline $\begin{array}{l}\text { Arellano-Bond Test for } \\
\operatorname{AR}(2)-\operatorname{Pr}>\mathrm{z}\end{array}$ & 0.892 & 0.293 & 0.365 \\
\hline Sargan Test & $24.08^{* * *}$ & 10.72 & 12.90 \\
\hline N. obs. & 546 & 546 & 546 \\
\hline $\begin{array}{l}\text { N. of Groups } \\
\text { (provinces) }\end{array}$ & 110 & 110 & 110 \\
\hline N. of Instruments & 18 & 18 & 18 \\
\hline
\end{tabular}


Robust standard errors

in parentheses, *

$\mathrm{p}<0.1, * * \mathrm{p}<0.05$, ***

$\mathrm{p}<0.01$

In model (a), results for the baseline specification are presented. Both lagged crime and education are statistically significant. We find that the lagged environmental crime determinant is positive and highly significant, meaning that the higher the level of green criminal conducts in the previous period, the higher the impact on the subsequent observed levels of crimes. With respect to education and its quadratic term, we observe that the signs of the coefficients are, respectively, positive and negative, and both highly statistically significant. This highlighted non-linear relation between education and environmental crime illustrates an unconventional finding: environmental crime with respect to the level of education increases at a decreasing rate. Similar to the results of previous studies (Germani et al., 2015), the positive sign of education can be explained by the economic nature of environmental crimes that can be considered corporate crimes (i.e., white-collar) requiring both high skills and investments. But, given the statistical significance of the quadratic term, this causal linkage is not linear, implying that an increase in the education level gradually reduces the increasing rate of environmental crime. This could be interpreted as a twofold effect exerted by education: the first is that environmental crime is confirmed to be a white-collar type of crime and the second is that education enhances awareness and self-perception of the risks and costs associated to environmental degradation. Despite the absence of second order serial correlation (AR2), the Sargan and Hansen tests do reject the null hypothesis of validity of the instruments.

Therefore, in model (b), we proceed by introducing socio-economic and institutional controls, such as judicial inefficiency and territorial extension of provinces (area) to the regressors' set. With respect to the lagged dependent variable and our strategic determinant, signs and statistical significance are in line with the previous estimation, reinforcing the non-linear relationship between education and environmental crime. However, judicial inefficiency and the area of the province do not have significant coefficients.

As a further and final robustness check, in model (c) household income and unemployment rate are added to the regressors set, as suggested by the literature to control for the illegal income opportunities. Interestingly, we find that the signs of Education coefficients, in both linear and quadratic terms, are, respectively, positive 
and negative, and both highly statistically significant. Environmental crime increases with income until it reaches a maximum, and then decreases as income keeps rising. $A$ possible interpretation would suggest that in the richest Italian provinces, individuals and firms are more likely to comply with environmental laws, and institutions are more likely to adopt stronger efforts in effective enforcement action to fight environmental crime. As a consequence, a further complementary interpretation would suggest that the business sector of those provinces, for opportunistic and strategic behaviour, might shift illegal environmental activities from wealthier to poorer (less-developed) provinces. This, in turn, could be interpreted as a form of environmental crime load displacement and environmental/social cost shifting. When looking at judicial inefficiency measure, we find a positive and significant result implying that the propensity to commit environmental crimes increases with proceedings' delay. As it is well known (Cohen, 2000; Polinsky and Shavell, 2000), increasing enforcement efforts and judicial efficiency of courts generates deterrence improvements. Our findings confirm that even when dealing with green crimes, in provinces with longer trials' length, where expectation of punishment is postponed in time (Becker, 1968) and courts are deemed to be less efficient, higher levels of criminal environmental infringements are observed. The size of the province (area) is still not statistically significant. Unemployment rate exerts a positive effect on the outcome variable; this finding partially confirms the assumption that the rate of unemployment captures an indirect measure of crime opportunity costs, generating a supplementary effect that induces economic agents to commit more crime (Andresen, 2013; Phillips and Land, 2012; Chalfin and Raphael, 2011; Mustard, 2010).

To check the robustness of our estimations for both model specifications (b) and (c), grounding the evaluation on the validity of the instruments, Sargan-Hansen tests provide a more unambiguous interpretation, confirming that instruments are not correlated with the error term. Moreover, as a further proof of consistent estimates, the Arellano-Bond test ensures the absence of second-order serial correlation; this confirms the efficiency of the estimation strategy adopted.

In order to provide a robustness check of the previous estimates, given that the level of total criminality could represent a missing confounding variable, we implement a new set of estimations (i.e., Panel-FE, Panel-RE and System-GMM) in which the dependent variable is represented by the incidence of environmental crimes over total crimes (Table 5). The overall outcome of the estimations provides a further confirmation to our research findings. 
Table 5 - Robustness check estimations: dep. variable EC/total crimes

\begin{tabular}{|c|c|c|c|}
\hline Variables & (a) & (b) & (c) \\
\hline $\begin{array}{l}\text { Dep. Variable: EC/Tot. } \\
\text { Crimes }\end{array}$ & P-FE & P-RE & System-GMM \\
\hline Environmental crime $_{t-1}$ & - & - & $\begin{array}{l}0.609 * * * \\
(0.031)\end{array}$ \\
\hline Education & $\begin{array}{l}127.768^{* * *} \\
(41.37)\end{array}$ & $\begin{array}{l}110.164^{* * *} \\
(39.31)\end{array}$ & $\begin{array}{l}66.682^{* *} \\
(27.49)\end{array}$ \\
\hline Education $^{2}$ & $\begin{array}{l}-27.713^{* * *} \\
(9.109)\end{array}$ & $\begin{array}{l}-24.359 * * * \\
(8.626)\end{array}$ & $\begin{array}{l}-14.342^{* *} \\
(6.042)\end{array}$ \\
\hline Judicial inefficiency & $\begin{array}{l}120.607 * \\
(72.36)\end{array}$ & $\begin{array}{l}77.845 \\
(76.97)\end{array}$ & $\begin{array}{l}394.510^{* * *} \\
(113.9)\end{array}$ \\
\hline Unemployment & $\begin{array}{l}0.015 \\
(0.0112)\end{array}$ & $\begin{array}{l}0.017 \\
(0.0120)\end{array}$ & $\begin{array}{l}0.049 \\
(0.043)\end{array}$ \\
\hline Households income & $\begin{array}{l}272.729 \\
(371.8)\end{array}$ & $\begin{array}{l}1429.512^{* * *} \\
(367.6)\end{array}$ & $\begin{array}{l}163.560^{* * *} \\
(45.72)\end{array}$ \\
\hline Households income ${ }^{2}$ & $\begin{array}{l}-14.066 \\
(18.66)\end{array}$ & $\begin{array}{l}-72.285^{* * *} \\
(18.44)\end{array}$ & $\begin{array}{l}-8.428^{* * *} \\
(2.274)\end{array}$ \\
\hline Population & $\begin{array}{l}4.116 \\
(5.068)\end{array}$ & $\begin{array}{l}0.872 \\
(5.308)\end{array}$ & $\begin{array}{l}-1.350 * \\
(0.753)\end{array}$ \\
\hline Tot. Crimes & $\begin{array}{l}-0.066 \\
(0.502)\end{array}$ & $\begin{array}{l}0.536^{* * *} \\
(0.0885)\end{array}$ & $\begin{array}{l}0.241^{* * *} \\
(0.0377)\end{array}$ \\
\hline Cons. & $\begin{array}{l}-151.208^{* * *} \\
(47.90)\end{array}$ & $\begin{array}{l}-124.481^{* * *} \\
(44.89)\end{array}$ & $\begin{array}{l}-796.869^{* * *} \\
(230.0)\end{array}$ \\
\hline
\end{tabular}




\begin{tabular}{|l|l|l|l|}
\hline $\begin{array}{l}\text { F-Stat. /Wald Test } \\
\text { (Time) }\end{array}$ & $8.08^{* * *}$ & $126.78^{* * *}$ & $439.929 * * *$ \\
\hline $\begin{array}{l}\text { Arellano-Bond for } \\
\text { AR(1) - Pr }>\text { z }\end{array}$ & - & - & 0.009 \\
\hline $\begin{array}{l}\text { Arellano-Bond for } \\
\text { AR(2) - Pr }>\text { z }\end{array}$ & - & - & 0.365 \\
\hline $\begin{array}{l}\text { Sargan Test } \\
\text { N. of obs. }\end{array}$ & - & - & 12.90 \\
\hline $\begin{array}{l}\text { N.. of Groups } \\
\text { (Provinces) }\end{array}$ & 110 & 548 & 546 \\
\hline $\begin{array}{l}\text { N. of Instruments } \\
\text { Robust standard errors }\end{array}$ & - & 110 & 110 \\
\hline $\begin{array}{l}\text { in parentheses, } * \\
\text { p<0.1, } * * \text { p }<0.05, * * * \\
\text { p<0.01 }\end{array}$ & & - & 18 \\
\hline
\end{tabular}

Moreover, following Lind and Mehlum (2010), we check the robustness of our previous findings on whether the relationship between education and environmental crimes is non-monotonic. As in Leonida et al. (2013), we test if the relationship is increasing at low values and decreasing at high values within the data range. The Lind and Mehlum (2010) test provides evidence for the rejection of the null hypothesis of the existence of a $U$-shaped relationship, and supports the non-monotonicity in the relationship between education and environmental crimes. $\underline{10}$ In all the estimated models, using the Fieller method for computing the confidence intervals, the null hypothesis is strongly rejected (1\%) and the extreme point is at about 2.29 in the education variable range.

Finally, to test furtherly the reliability of the quadratic specification, we estimate (3) and (4) using a previous semiparametric fixed effects estimator, providing a robustness check for the findings obtained with the system-GMM estimator. Therefore, we estimate the education determinant without specifying a functional form. In Figures 2 and 3, we plot the nonparametric kernel-based estimate of $g(E d u)$ in (3) and (4). We can observe that the nonparametric estimate (red line) depicts a sharp inverted $U$ shaped curve. This result provides an "unconstrained" sounding reassessment of the 
non-linear relationship between education and environmental crime obtained with the previous parametric approaches.

Figure 2 - Baltagi and Li (2002) semi-parametric linear prediction

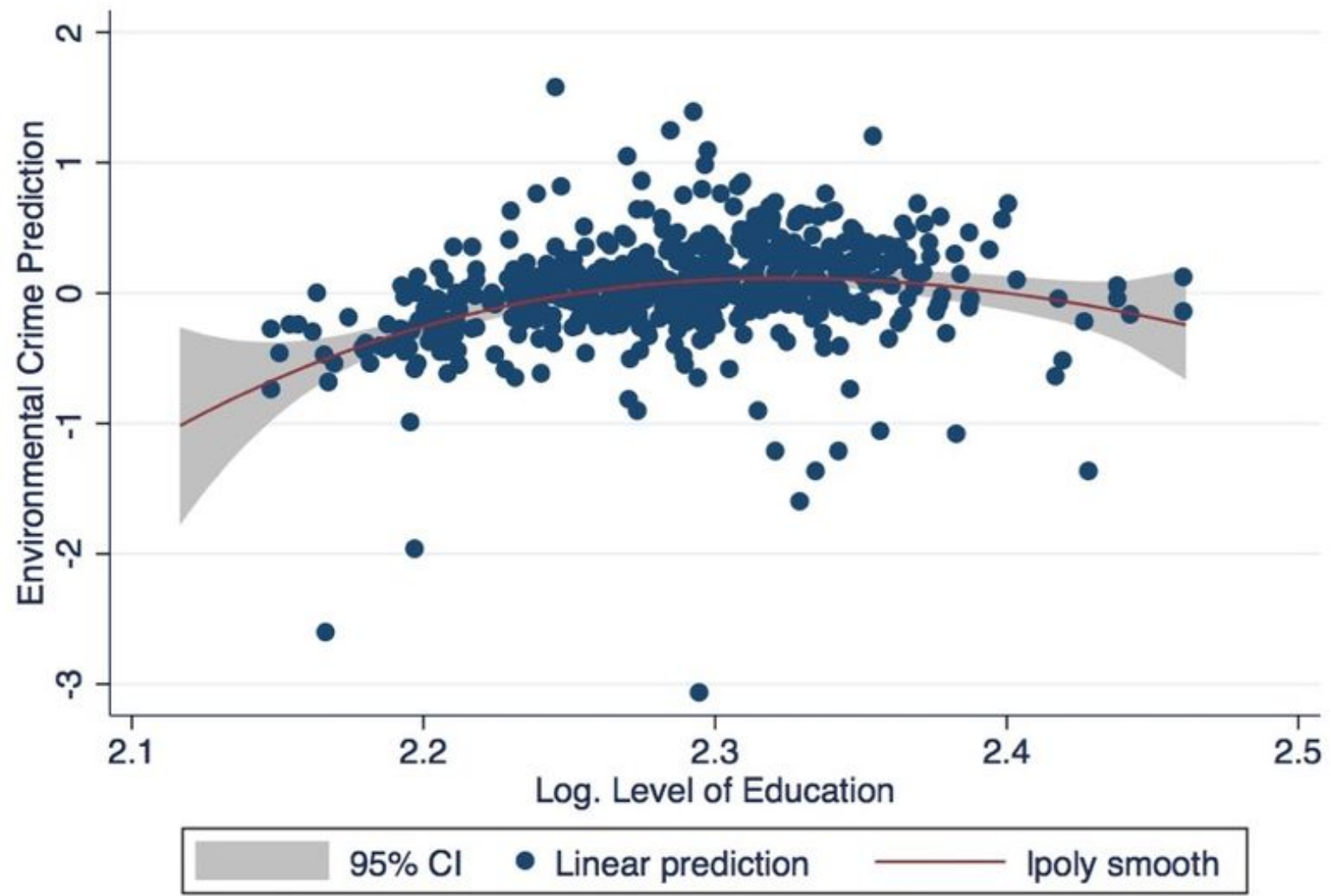

kernel $=$ epanechnikov, degree $=4$, bandwidth $=.52$, pwidth $=.77$

Figure 3 - Baltagi and Li (2002) semi-parametric linear prediction: dep. variable EC/total_crimes 


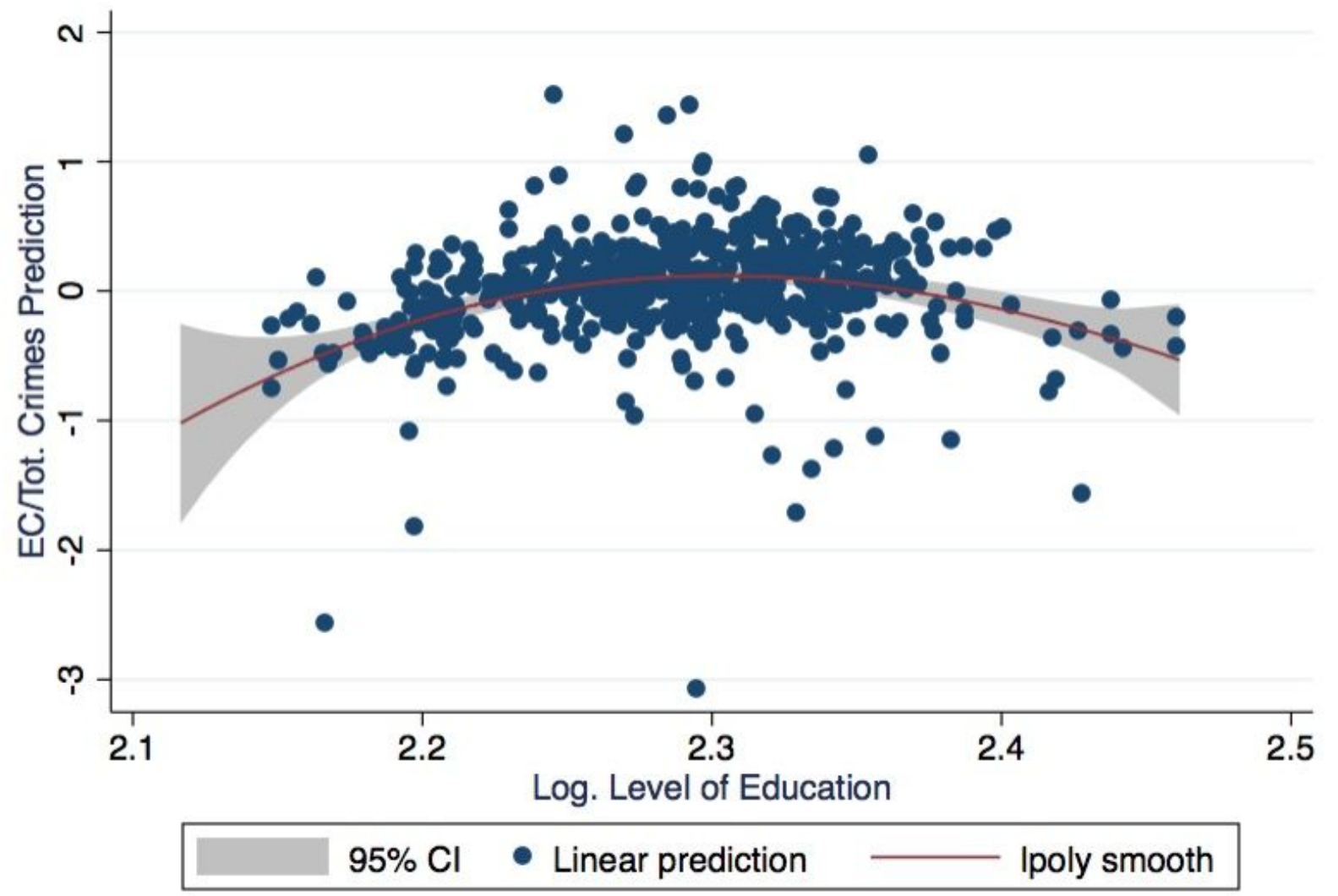

kernel $=$ epanechnikov, degree $=4$, bandwidth $=.64$, pwidth $=.96$

\section{CONCLUSIONS}

The empirical analysis performed has allowed us to evaluate the role of education in the explanation of environmental crime. The findings obtained, which are very robust over the different specifications and approaches employed, reveal that education might be a prime driver of environmental crime and that there is support for a U-inverted shape in such relationship.

Policy makers, in Italy, alongside the traditional enforcement tools (e.g., probability of detection, severity of punishment) should give stronger consideration to the promotion of educational policy able to increase awareness of the environmental wealth, as an indirect channel to reduce environmental crimes. These findings appear to concur with those in other studies (Usher, 1997; Kountouris and Remoundou, 2016) that show that education improves the understanding of social values and develops a sense of belonging to the community promoting virtues related to work and honesty; this is consistent with the mechanisms of positive externalities associated, above all, with human capital in the new growth theories (Lucas, 1988) for which investments in 
human capital increase the productivity of labour that has a positive contribution on the output growth. Along this line, Amore et al. (2019) have recently demonstrated that CEO education is associated with greater environmental awareness (i.e., highly educated CEOs exhibit greater concerns for climate change and significantly improve firms' energy efficiency) confirming the argument that education is not only beneficial for individuals but may generate benefits for the entire society (Krueger and Lindahl, 2001). This points to the importance of nurturing environmental values using education as a major cultural transmission mechanism and suggests that the design and implementation of environmental policies should take into account that a culture of legality can be influenced and transmitted by education. Moreover, this area of public intervention can be strategic to promote North/South economic territorial rebalancing: policies that aim to raise education levels have the advantage of reducing crime and increasing the accumulation of human capital of the population. Southern Italy represents a case of lack of industrialization and this characteristic has conditioned its growth and development process; in turn, it is plausible to assume that these clear differences are reflected in differences in crime rates (Buonanno and Leonida, 2003).

The Italian context is a peculiar case to study, not only for the long-standing dualism between the more developed northern/central and the less developed southern Italian provinces, but also for the well-known presence of organized crime in many economic sectors. In this perspective, the estimates obtained show that environmental crime is non-linearly related to income, implying that boosting innovation policies and promoting investments in green policies, eco-sustainability and circular economy, can represent a challenging new policy option that can pave the way towards both economic growth opportunities and environmental crime abatement. Indeed, our results support the view that criminal environmental conducts are influenced by the inefficiency of judicial courts, measured in terms of delays in criminal proceedings. In the light of all these issues, our findings suggest that identifying the potential beneficial effects of education on the environment - that go well beyond economic growth impacts - might help designing smarter policies. This opens the way to enhance policy efforts towards a harmonization of environmental enforcement actions throughout the country to avoid the phenomena of environmental crime displacement (i.e., the effect of pollution havens especially in the South of Italy) and an enhancement of the criminal justice's efficiency to fight environmental crime stratification.

\section{References}


Amore M.D., M. Bennedsen, B. Larsen, P. Rosenbaum (2019). CEO education and corporate environmental footprint, Journal of Environmental Economics and Management, 94: 254-273.

Andresen M. A. (2013). Unemployment, Business Cycles, Crime, and the Canadian Provinces, Journal of Criminal Justice, 41 (4): 220-27.

Arellano M., S. Bond (1991). Some Tests of Specification for Panel Data: Monte Carlo Evidence and an Application to Employment Equations, Review of Economic Studies, 58(2): 277-297.

Arellano M., O. Bover (1995). Another Look at the Instrumental Variable Estimation of Error-Components Models, Journal of Econometrics, 68(1): 29-51.

Baltagi B.H., D. Li (2002). Series estimation of partially linear panel data models with fixed effects. Annals of Economics and Finance, 3(1): 103-116.

Becker G. (1968). Crime and Punishment: An Economic Approach, The Journal of Political Economy, 76 (2): 169-217.

Becker G.S. (1967). Human Capital and the Personal Distribution of Income: An Analitical Approach, Woytinsky Lecture 1, University of Michigan, Institute of Public Administration, Ann Arbor.

Becker G.S., C. Mulligan (1997). The endogenous determination of time preference, Quarterly Journal of Economics, 112:729-758.

Bell B., R. Costa, S. Machin (2016). Crime, compulsory schooling laws and education, Economics of Education Review 54: 214 - 226.

Ben-Porath Y. (1967). The production of human capital and the life cycle of earnings, The Journal of Political Economy, 75(4):352-65.

Blundell R., S. Bond (1998). Initial conditions and moment restrictions in dynamic panel data models, Journal of Econometrics, 87(1): 115-143.

Bun M.J.G. (2014). Identifying the impact of deterrence on crime: internal versus external instruments, Applied Economics Letters, 22(3): 204-208.

Bun M.J.G., Kelaher R., V. Sarafidis, D. Weatherburn (2020). Crime, deterrence and punishment revisited, Empirical Economics, 59: 2303-2333. 
Buonanno P., L. Fergusson, J.F. Vargas (2017). The Crime Kuznets Curve, Journal of Quantitative Criminology, 33(4):753-782.

Buonanno P., L. Leonida (2009). Non-market effects of education on crime: Evidence from Italian regions, Economics of Education Review, 28: 11-17.

Buonanno P., D. Montolio (2008). Identifying the socio-economic and demographic determinants of crime across Spanish provinces, International Review of Law and Economics, 28: 89-97.

Buonanno P., L. Leonida (2006). Education and Crime, Applied Economics Letters, 13; 709-713.

Buonanno P., L. Leonida (2003). L’approccio economico alla criminalità e una analisi econometrica del caso italiano, in Comportamento criminale, Letizi M. (ed.), Ecomafie e Smaltimento dei Rifiuti, Soveria Mannelli: Rubbettino Editore.

Cano-Urbina J., L. Locner (2019). The effect of education and school quality on female crime, Journal of Human Capital, vol. 13(2): 188-235.

Chalfin A., J. McCrary (2017). Criminal Deterrence: A Review of the Literature, Journal of Economic Literature, 55(1); 5-48.

Chalfin A., S. Raphael (2011). Work and Crime, in The Oxford Handbook of Crime and Criminal Justice, edited by M. Tonry, pp. 444 - 478, Oxford and New York: Oxford University Press.

Cohen M.A. (2000). Empirical research on the deterrent effect of environmental monitoring and enforcement, Environmental Law Reporter 30:10245-52.

Costantini V., M. Mazzanti, A. Montini (2013). Environmental Performance, Innovation and spillovers: evidence from a regional NAMEA, Ecological Economics, 89 (C):101114.

Cullen J., B. Jacob, S. Levitt (2006). The effect of school choice on participants: Evidence from randomized lotteries, Econometrica, 74: 1191-1230.

De Falco G. (2014). Traffico illecito dei rifiuti: un approccio giudiziario, in Gazzetta Ambiente 4, pp. 71 - 75.

Deming D. (2011). Better schools, less crime? Quarterly Journal of Economics, 126: 2063-2115. 
D’Alisa G., A.R. Germani, P.M. Falcone, P. Morone (2017). Political ecology of health in the Land of Fires: a hotspot of environmental crimes in the South of Italy, Journal of Political Ecology, vol. 24: 59-86.

D’Amato A., M. Mazzanti, A. Montini (2013). Waste Management in Spatial environments, Routledge, London.

Ehrlich I. (1973). Participation in illegitimate activities: A theoretical and empirical investigation, Journal of Political Economy, 81: 521-565.

Fajnzylber P., D. Lederman, N. Loayza (2002). Inequality and violent crime, Journal of Law and Economics, 45; 1-39.

Freeman S., J. Grogger, J. Sonstelie (1996). The spatial concentration of crime, Journal of Urban Economics, 40:216-231.

Hansen, L. (1982). Large Sample Properties of Generalized Method of Moments Estimators, Econometrica, 50(4), 1029-1054.

Germani A.R., A. Ker, A. Castaldo (2020). On the existence and shape of an environmental crime Kuznets Curve: A case study of Italian provinces, Ecological Indicators, https://doi.org/10.1016/j.ecolind.2019.105685

Germani A.R., A. Pergolizzi, F. Reganati (2015). Illegal trafficking and unsustainable waste management in Italy: evidence at the regional level, Journal of Security and Sustainability Issues, 4(4): 369-389.

Glaeser E.L., B. Sacerdote (1999). Why is there more crime in cities? The Journal of Political Economy, 107 (6/2): 225-258.

Grogger J. (1998). Market Wages and Youth Crime, Journal of Labor Economics, 16, 756- 91. Grogger J. (1995). The Effect of Arrests on the Employment and Earnings of Young Men, Quarterly Journal of Economics, 110:51-71.

Groot W., H. M. van den Brink (2010). The effects of education on crime, Applied Economics, 42: 279- 289.

Harlow C. (2003). Education and correctional populations, Bureau of Justice Statistics Special Report, NCJ 195670.

Hjalmarsson R. (2008). Criminal justice involvement and high school completion, Journal of Urban Economics, 63:613-30. 
Hjalmarsson R., H. Holmlund, M. J. Lindquist (2015). The effect of education on criminal convictions and incarceration: causal evidence from micro-data, The Economic Journal, 125: 1290-1326.

Holtz-Eakin D., W. Newey, and H.S. Rosen (1988). Estimating Vector Autoregressions with Panel Data, Econometrica, 56, n. 6.

Hudson R. (2014). Thinking through the relationships between legal and illegal activities and economies: Spaces, flows and pathways, Journal of Economic Geography, 14 (4):775-795.

Kountouris, Y., and K. Remoundou (2016). Cultural influence on preferences and attitudes for environmental quality, Kyklos, 69(2): 369-397.

Krueger A., M. Lindahl (2001). Education for growth: why and for whom? Journal of Economic Literature, 39:1101-1136.

Lance L., M. Enrico (2004). The effect of education on crime: Evidence from prison inmates, arrests, and self-reports, The American Economic Review, 94: 155-189.

Legambiente (2018, 2019). Ecomafia 2018, 2019, Edizioni Ambiente, Milan, Italy.

Leonida L., D. Maimone Ansaldo Patti, P. Navarra (2013). Testing the Political Replacement Effect: A Panel Data Analysis, Oxford Bulletin of Economics and Statistics, 75: 785-805.

Lochner L. (2020). Education and crime, in The Economics of Education - A comprehensive overview, (edited by S. Bradley and C. Green), pp. 109-1771, second edition Academic Press, https://doi.org/10.1016/B978-0-12-815391-8.01001-6.

Lochner L. (2011a). Non-Production Benefits of Education: Crime, Health, and Good Citizenship, Hanushek E., S. Machin and L. Woessmann (eds.), Handbook of the Economics of Education, vol. 4, Amsterdam: Elsevier.

Lochner L. (2011b). Education Policy and Crime, P. J. Cook, J. Ludwig, and J. McCrary (eds.), Controlling Crime: Strategies and Tradeoffs, pp. 465-515, University of Chicago Press, https://www.nber.org/system/files/chapters/c12090/c12090.pdf.

Lochner L. (2007). Individual perceptions of the criminal justice system, American Economic Review, 97(1): 444-460. 
Lochner L. (2004). Education, work, and crime: a human capital approach, International Economic Review, 45: 811-43.

Lochner L., E. Moretti (2004). The effect of education on crime: Evidence from prison inmates, arrests, and self-reports, American Economic Review, 94 (1):155-189.

Lucas, R. E. Jr. (1988). On the mechanics of economic development, Journal of Monetary Economics. vol. 22: 3 - 42.

Machin S., O. Marie, S. Vujic' (2011). The crime reducing effect of education, Economic Journal, 121(552): 463-84.

Machin S., C. Meghir (2004). Crime and economic incentives, Journal of Human Resources, vol. 39: 958-79.

Mazzanti M., A. Montini, F. Nicolli (2012). Waste dynamics in economic and policy transitions: decoupling, convergence and spatial effects, Journal of Environmental Planning and Management, 55(5): 563-81.

Mazzanti M., A. Montini, R. Zoboli (2008). Municipal waste generation, socio-economic drivers and waste management instruments, Journal of Environment and Development, 17:51-69.

Mustard D. B. (2010). How Do Labor Markets Affect Crime? New Evidence on an Old Puzzle, Institute for the Study of Labor, Discussion Paper 4856.

Myers S. (1982). Crime in urban areas: New evidence and results, Journal of Urban Economics, 11:148-158.

Nellemann C., R. Henriksen, A. Kreilhuber, D. Stewart, M. Kotsovou, P. Raxter, E. Mrema, S. Barrat, (eds) (2016). The Rise of Environmental Crime - A Growing Threat to Natural Resources Peace, Development and Security, A UNEP-INTERPOL Rapid Response Assessment, United Nations Environment Programme and RHIPTO Rapid Response-Norwegian Center for Global Analyses.

Ochsen C. (2010). Crime and labor market policy in Europe, International Review of Law and Economics, 30: 52-61.

Pergolizzi A. Emergenza Green corruption. Come la corruzione divora l'ambiente, Andrea Pacilli ed., 2019. 
Phillips J., K. C. Land (2012). The Link between Unemployment and Crime Rate Fluctuations: An Analysis at the County, State, and National Levels, Social Science Research, 41 (3): 681-694.

Polinsky A.M., S. Shavell (2000). The Economic Theory of Public Enforcement of Law, Journal of Economic Literature, 38(1): 45-76.

Roberti F. (2014) Audizione del Procuratore Nazionale Antimafia. Commissione parlamentare d'inchiesta sulle attività illecite connesse al ciclo dei rifiuti. XVII Legislatura, available at http://www.camera.it/leg17/210? commissione $=39 \&$ \&annomese $=201411 \&$ view $=$ filtered .

Roodman D. (2009). A Note on the Theme of Too Many Instruments, Oxford Bulletin of Economics and Statistics, 71, 1 (2009) 0305-9049

Sargan J.D. (1958). The Estimation of Economic Relationships using Instrumental Variables, Econometrica, 26(3): 393-415.

Tauchen H., A. Witte, H. Griesinger (1994). Criminal deterrence: revisiting the issue with a birth cohort, Review of Economics and Statistics, 76: 399 - 412.

Veselak K.M. (2015). The Relationship between Educational Attainment and the Type of Crime Committed by Incarcerated Offenders, Journal of Correctional Education, 66(2): 30-56.

Witt R., A. Clarke, N. Fielding (1999). Crime and economic activity: a panel data approach, British Journal of Criminology, 39: 391-400.

\section{Footnotes}

1. Lochner (2004) argues that education reduces crime because it increases the opportunity costs from forgone earnings and expected costs of incarceration. $\longleftarrow$ 2. This result is explained considering that higher educated individuals generally earn more than lower educated one, and the potential benefits of tax evasion and fraud increase with taxable earnings. Another possible explanation is that higher educated individuals are more knowledgeable about the possibilities for committing tax fraud. $\subseteq$

3. Such as the form (so called, Formulario Identificativo dei Rifiuti) that follows the transfer of waste. $€$ 
4. Unfortunately, the provincial data is available only at the aggregate level (across the four categories). $\_$

5. This is the total number of environmental violations detected which follow the criminal investigation phase. $€$

6. The calculated average length indicates the average period of permanence of a proceeding occurring in a judicial office and is calculated as the ratio between the value obtained by adding the initial pending (IP) to the final pending (FP) and the value of the sum of the registered (I) with the defined (D). This is an indicator already used by ISTAT to calculate the average duration of the proceedings: Average length in days $=[(\mathrm{IP}+\mathrm{FP}) /(\mathrm{I}+\mathrm{D})] * 365 . \underline{-}$

7. Note that trial and appeal delays are one of the major problems associated with the inefficiency of justice in Italy. We use all criminal trials to deal with endogeneity. $\bullet$

8. This method is particularly suitable in the cases of panel with a small-time horizon $(T)$ and a relatively large number of observations $(N)$. Moreover, this allows us to catch the adjustment path of our dependent variable by combining it into a single system, lagged level and differences. $\_$

9. We are grateful to an anonymous referee for pointing this out. $\uplus$

10. The outcomes of the tests are available upon request. $\triangleq$ 